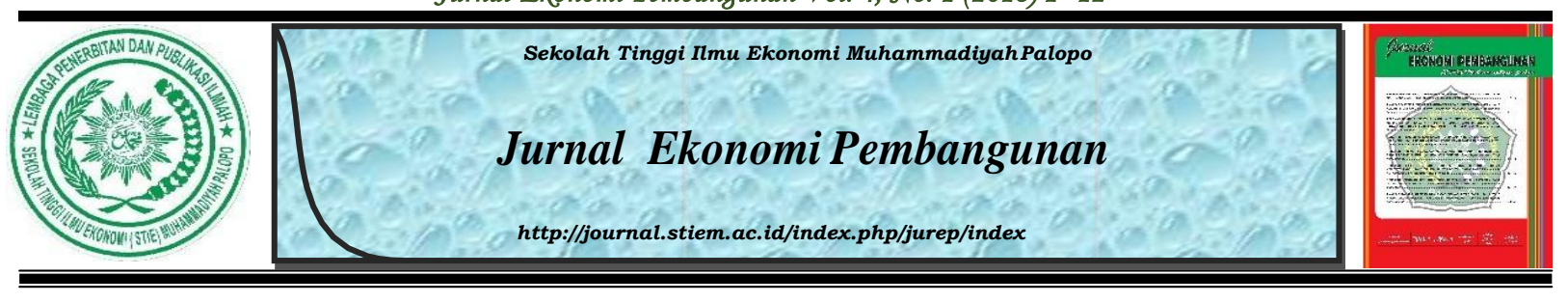

\title{
Pengaruh Luas Lahan, Modal Dan Tenaga Kerja Terhadap Pendapatan Petani Tambak Udang Di Desa Tamuku Kecamatan Bone-Bone Kabupaten Luwu Utara
}

Hikmawati

STIE Muhammadiyah Palopo

\section{INFO NASKAH}

Diserahkan O3Mei 2018

Diterima

22 Mei 2018

Diterima dalam revisi

24 Mei 2018

Diterima dan disetujui 12 Juni 2018

Kata Kunci:

Luas lahan, modal dan

tenaga kerja

\section{ABSTRAK}

Terdapat banyak factor yang dapat mempengaruhi pendapatan petani tambak diantaranya tingkat pendidikan, tingkat usia,, modal dan kinerja. Untuk mencapai pendapatan yang tinggi petani harus memperhatikan luas lahan, modal, dan tenaga kerja. Penelitian ini bertujuan untuk meningkatkan pendapatan petani tambak udang di Desa Tamuku Kecamatan Bone-Bone Kaupaten Luwu Utara. Data yang digunakan adalah data primer yang di peroleh dari penyebaran kuesioner kepada responden. Data dianalisis menggunakan kuantitatif melalui metode anilisis regresi linear berganda untuk menjawab masalah penelitian dan uji hipotesis. Hasil penelitian menunjukkan bahwa luas lahan, modal dan tenaga kerja berpengaruh positif dan signifikan terhadap pendapatan petani tambak udang di Desa Tamuku Kecamatan Bone-Bone Kabupaten Luwu Utara dengan kontribusi coefficient beta 22,623. 


\section{Pendahuluan}

Indonesia merupakan negara kepulauan yang di dalamnya terdapat berbagai macam potensi. Sebagian besar wilayah Indonesia merupakan daerah lautan dengan luas mencapai 5,8 juta $\mathrm{km}$ persegi (75 persen dari luas total wilayah) dengan garis pantai $81.000 \mathrm{~km}$ atau sekitar 14 persen dari garis pantai dunia. Dengan demikian wilayah geogrfis negara Indonesia mempunyai potensi yang besar dalam pengembangan sektor perikanan.

Produk Domestik Bruto (PDB) sektor perikanan selama periode 2003-2006 mengalami kenaikan rata-rata sebesar 15,5 persen per tahun. Hal ini menunjukkan bahwa pertumbuhan sektor perikanan setiap tahunnya terus mengalami kenaikan. Jika dibandingkan dengan sektor tanaman pangan, perkebunan, peternakan, dan kehutanan maka kenaikan PDB rata-rata sektor perikanan paling tinggi. Oleh karena itu sektor perikanaan merupakan sektor yang mempunyai prospek dan potensi yang besar. Produksi perikanan Indonesia bersumber dari perikanan tangkap dan perikanan budidaya. Pada tahun 1999 produksi perikanan tangkap mendominasi, mencapai 81,95 persen terhadap perikanan budidaya akan tetapi pada tahun 2006 .

Usaha perikanan budidaya diperkirakan akan mempunyai peran yang penting dalam jangka panjang karena sumber daya laut akan semakin berkurang yang disebabkan oleh sifatnya yang terbuka untuk di manfaatkan oleh siapa saja dan termasuk sumber daya alam yang mempunyai waktu lama untuk bisa diperbaharui.

Potensi yang dimiliki oleh sektor perikanan ini perlu dikelola dengan baik dan optimal agar mampu menjadi penggerak utama perekonomian nasional. Dalam pelaksanaannya, usaha pengembangan sektor perikanan perlu melibatkan seluruh pihak, seperti pemerintah, pengusaha, pembudidaya dan stakeholder. Pemerintah mempunyai peran yang paling penting karena mempunyai kewenangan dalam pengambilan kebijakan tingkat mikro dan makro. Kebijakan-kebijakan yang diambil diharapkan mengarah pada komoditas-komoditas yang mempunyai keunggulan supaya kebijakan yang diambil lebih efektif dan terarah. Udang merupakan komoditas perikanan yang mempunyai nilai ekonomi cukup tinggi. Bukan hanya itu, udang juga mempunyai pasar yang luas terutama di luar negeri.

Kecenderungan yang terjadi dalam budidaya tambak udang, khususnya yang menetapkan teknologi semi insentif dan insentif adalah memburuknya keadaan lingkungan tambak sejalan dengan berlansungnya masa pemeliharaan atau dengan kata lain cenderung mencari lingkungannya sendiri. Dampaknya adalah stress yang akan memperlemah kondisi udang, 
sehingga mudah terserang penyakit. Selain dari itu, lingkungan tambak dapat pula di cemari oleh polutan yang berasal dari lingkungan sekitar seperti pemukiman, industry, persawahaan dan lain-lain. Masalah lain yang sering terjadi adalah masalah permodalan yang menyangkut biaya besar utuk biaya pembangunan tambak baru yang lengkap dengan saluran sekunder dan tersier.

Keadaan tersebut sangat relevan dengan usaha pemeritah sulawesi selatan untuk mendorong dan meningkatkan produksi melalui program perwilayaan komidititas sehingga dengan adanya peningkatan produksi tersebut di harapkan secara langsung akan dapat meningkatkan pendapatan petani tambak khususnya petani tambak yang dapat di Desa Tamuku Kecamatan Bone-Bone.

Jadi kebijaksaaan pemerintah dalam hal pelaksanaan program perwilayaan komoditas ini telah memberikan dampak yang positif terhadap pengembangan usaha pertaniaan dalam hal ini sub sector pertambakan di Kecamatan Bone-Bone pada khususnya dan petani tambak di Kabupaten Luwu. Oleh karena itu komoditas udang merupakan primadona ekspor hasil perikanan yang mempunyai peluang yang cukup cerah dimasa yang akan datang dimana memiliki nilai ekonomis yang tinggi baik untuk pasaran local maupun untuk pasaran ekspor, maka para petani tambak yang dahulunya menganggap udang yang hidup di tambak sebagai hama, mempunyai rasa daging yang lezat, serta mempunyai protein yang banyak menyebabkan petani tambak tersebut mengadakan penagkaran dan penangkapan walau dengan alat yang cukup sederhana dan tradisional tapi kita harapkan para petani tambak nantinya dapat meningkatkan hasil yang diharapkan tanpa merusak kelestarian lingkungan ikan tersebut Maka untuk mengetahui secara jelas tentang Pengaruh luas lahan, modal dan tenaga kerja terhadap pendapatan petani tambak udang di Desa Tamuku Kecamatan BoneBone dapat di ketahui dengan melihat dan membahas secara lebih seksama.

Adapun tujuan penelitian ini yaitu untuk meningkatkan pendapatan petani tambak udang di Desa Tamuku Kecamatan Bone-Bone Kabupaten Luwu Utara.

\section{Metode Penelitian}

\subsection{Pendekatan Penelitian}

Dalam penelitian ini, metode yang di lakukan antara lain.

a. pertama, observasi, yakni teknik pengumpulan data yang dilakukan dengan cara pengamatan terhadap obyek, misalnya perlengkapan jaring atau keramba bambu yang digunakan dalam membudidayakan udang, 
b. kedua, interview, yakni teknik pengumpulan data dengan cara mengadakan tanya jawab secara lisan terhadap responden,

c. ketiga, kuesioner, yakni suatu teknik pengumpulan data dengan cara memberikan beberapa pertanyaan yang harus dijawab oleh masyarakat petani tambak sebagai responden

tahapan pertama pengumpulan data penelitian ini, di mjulai dari penepatan variabelvariabel yang akan di teliti. Dari variabel-variabel diberikan defenisi operasional, selanjutnya di tentukan indicator yang akan di ukur. Dari indicator ini akan dijabarkan menjadi daftar/tabel isian data/ koesioner. Daftar isian dta tersebut menjdi instrument penelitian sebagai media pengambilan data primer dari responden.

Data yang akan di jarring/dikumpulkan adalah data kuantitatif dan data kualitatif. Data kuantitatif sebagai data pokok, sedangkan data kualitatif adalah data pendukung. Data di maksud, dijaring/dikumpulkan melalui koesioner yang berisi jumlah pertanyaan kepada responden. Item-item kuesioner disusun berdasarkan urutan variabel dan indicator variabel. Dalam kuesioner terdapat sejumlah pernyataan yang ditunjukkan kepada untuk menggali persepsi terdapat subjek/objek yang akan diteliti. Kuesioner didistribusikan kepada 20 responden yang terpilih sebgai sampel penelitian yang ada diwilayah Desa Tamuku Kecamatan Bone-Bone Kabupaten Luwu Utara. Kuesioner yang didistribusikan dan telah dii isi/dijawab oleh responden, kemudian di kumpulkan oleh peneliti dengan cara mendatangi setiap responden yang terpilih sebagai sampel penelitian.

\subsection{Populasi dan Sampel}

Populasi adalah jumlah keseluruhan dari unit atau obyek analisa yang ciri-ciri karakteristiknya hendak diduga. Populasi dalam penelitian ini adalah semua petani tambak udang yang ada di Desa Tamuku Kecamatan Bone-Bone Kabupaten Luwu Utara yang berjumlah 43 petani tambak. Sekaligus menjadi sampel dalam penelitian ini. 


\subsection{Teknik Pengumpulan Data}

Bertitik tolak dari masalah dan hipotesis yang telah dikemukakan sebelumnya maka dalam membahas dan menganalisis permasalahan dan sekaligus untuk membuktikan hipotesis yang di tetapkan bahwa faktor luas lahan, modall dan tenaga kerja berpengaruh positif terhadap pendapatan petani tambak udang di Desa Tamuku Kecamatan Bone-Bone Kabupaten Luwu Utara, maka di gunakan rumus persamaan regresi linear berganda

$$
\mathrm{Y}=\mathrm{a}+\mathrm{b}_{1} \cdot \mathrm{X}_{1}+\mathrm{b}_{2} \cdot \mathrm{X}_{2}+\mathrm{b}_{3} \cdot \mathrm{X}_{3}+\mathrm{e}
$$

Dimana :

$\mathrm{Y}=$ tingkat pendapatan petani tambak udang

$\mathrm{X}_{1}=$ luas lahan

$\mathrm{X}_{2}=$ modal

$\mathrm{X}_{3}=$ tenaga kerja

$\mathrm{E}=$ kostanta

a dan $b=$ adalah parameter dari kedua variable tersebut

\section{Hasil dan Pembahasan}

\subsection{Hasil}

hasil penelitian ini memberikan gambaran tentang data-data mengenai inovasi sumber daya perusahaan terhadap keunggulan bersaing

Tabel 4.6

Descriptive Statistics

\begin{tabular}{|l|r|r|r|}
\hline & Mean & \multicolumn{1}{|c|}{ Std. Deviation } & N \\
\hline Y & 9.4419 & 1.70855 & 43 \\
X1 & 12.6279 & 1.90267 & 43 \\
X2 & 12.3023 & 1.79331 & 43 \\
X3 & 11.7907 & 1.14555 & 43 \\
\hline
\end{tabular}

Sumber : Data di olah, 2018

Berdasarkan hasil perhitungan pada tabel 4.9 Tersebut, dengan sampel pengamatan sebanyak 43 sampel. Variable dependen pendapatan mempunyai nilain mean sebesar 9,4419 dan standar deviasi sebesar 1,70855. Nilai rata-rata (mean) lebih besar dibandingkan standar 
deviasi menunjukkan bahwa data terdistribusi dengan baik.

Variabel luas lahan mempunyai nilai mean sebesar 12,6279 dan standar deviasi sebesar 1,90267 nilai rata-rata (mean) lebih besar di bandingkan standar deviasi menunjukkan bahwa data terdistribusi dengan baik.

Variabel modal mempunyai nilai mean sebesar 12,3023 dan standar deviasi sebesar 1,79331 nilai rata-rata (mean) lebih besar di bandingkan standar deviasi menunjukkan bahwa data terdistribusi dengan baik.

Variabel tenaga kerja mempunyai nilai mean sebesar 11,7907 dan standar deviasi sebesar 1,14555 nilain rata-rata (mean) lebih besar di bandingkan standar deviasi menunnjukkan bahwa data terdistribusi dengan baik

\subsection{Analisis Regresi Linear Berganda}

Analisis regresi linear berganda di gunakan untuk mengetahui bagaimana hubungan antara ketiga sub variabel, dalam hal ini variabel pendapatan, luas lahan, modal, dan tenaga kerja. Berdasarkan hasil pengolahan data yang dilakukan dengan menggunakan SPSS V.21 for windows, maka hasilnya secara lengkap di sajikan dalam tabel di bawah ini :

Tabel 4.10

\section{Hasil regresi linear berganda}

Coefficients $^{\mathrm{a}}$

\begin{tabular}{|c|r|r|r|r|r|}
\hline \multirow{2}{*}{ Model } & \multicolumn{2}{|c|}{$\begin{array}{c}\text { Unstandardized } \\
\text { Coefficients }\end{array}$} & $\begin{array}{c}\text { Standardized } \\
\text { Coefficients }\end{array}$ & \multicolumn{2}{|c|}{} \\
\cline { 2 - 4 } & B & Std. Error & Beta & \multicolumn{1}{|c|}{$\mathrm{t}$} & \multicolumn{2}{|c|}{ Sig. } \\
\hline $1 \quad$ (Constant) & 22.623 & 2.746 & & 8.239 & .000 \\
x1 & -.298 & .112 & -.332 & -2.656 & .011 \\
x2 & -.371 & .120 & -.389 & -3.086 & .004 \\
x3 & -.412 & .185 & -.276 & -2.222 & .032 \\
\hline
\end{tabular}

a. Dependent Variable: y

Sumber : data di olah tahun 2018

Dari tabel 4.10 di atas di peroleh persamaan regresi linear berganda pada penelitian ini adalah sebagai berikut :

$$
Y=22,623+\left(-0,298 X_{1}-0,371 X_{2}-0,412 X_{3}\right)
$$


Persamaan regresi tersebut memperlihatkan bahwa luas lahan, modal, dan tenaga kerja konstan maka pendaptan akan naik sebasar 22,623. Apabila variabel luas lahan naik sebesar $1 \%$ sedangkan variabel lain ( luas lahan) dianggap konstan maka pendapatan naik sebesar 0,298. Apabila variabel modal naik sebesar $1 \%$ sedangkan variabel lain ( modal ) dianggap konstan maka pendapatan naik sebesar 0,371. Apabila variabel tenaga kerja naik sebesar $1 \%$ sedangkan variabel lain ( tenaga kerja ) dianggap konstan maka pendaptan naik sebesar 0,412.

\subsection{Pengujian hipotesis}

a. Uji t

Uji t di gunakan untuk mengetahui signifikan atau tidaknya suatu pengaruh variabel independen secara parsial atas variabel dependen. Untuk menguji hipotesis tersebut maka terlebih dahulu menentukan criteria tinglat signifikan yaitu sebesar $5 \%=0,05$ kemudian di bandingkan dengan hasil signifikan yang telah di olah menggunakan SPSS V.21 output uji t pada tabel berikut :

Tabel 4.12

\section{Hasil regresi uji t}

\section{Coefficients $^{\mathrm{a}}$}

\begin{tabular}{|c|c|c|c|c|c|}
\hline \multirow[b]{2}{*}{ Model } & \multicolumn{2}{|c|}{$\begin{array}{c}\text { Unstandardized } \\
\text { Coefficients }\end{array}$} & \multirow{2}{*}{$\begin{array}{c}\text { Standardized } \\
\text { Coefficients }\end{array}$} & \multirow[b]{2}{*}{$\mathrm{T}$} & \multirow[b]{2}{*}{ Sig. } \\
\hline & B & Std. Error & & & \\
\hline $1 \quad$ (Constant) & 22.623 & 2.746 & & 8.239 & .000 \\
\hline $\mathrm{x} 1$ & -.298 & .112 & -.332 & -2.656 & .011 \\
\hline $\mathrm{x} 2$ & -.371 & .120 & -.389 & -3.086 & .004 \\
\hline $\mathrm{x} 3$ & -.412 & .185 & -.276 & -2.222 & .032 \\
\hline
\end{tabular}

a. Dependent Variable: y

Sumber : data diolah tahun 2018

Berdasarkan tabel 4.12 di atas nilai uji t yang diperoleh secara parsial dan perhitungan $t_{\text {tabel }}$ dengan criteria tingkat signifikan sebesar 0,05 dan derajat kebebasan $(\mathrm{dk})=\mathrm{n}-\mathrm{k}$ atau 43-3-1 ( $\mathrm{n}$ adalah jumlah sampel dan $\mathrm{k}$ adalah jumlah variabel independen), maka diperoleh $\mathrm{t}$ tabel sebesar 2,023. Berdasarkan nilai uji t yang di peroleh, secara parsial pengaruh variabel independen terhadap variabel dependen adalah sebagai berikut : 
1). Luas lahan di peroleh $t_{\text {hitung }}$ sebesar $-2,656$ dan $t_{\text {tabel }}$ sebesar 2,023 maka diperoleh hasil $t_{\text {hitung }}<\mathrm{t}_{\text {tabel }}$ atau $-2,656<2,023$ dengan tingkat signifikan sebesar 0,011<0,05 yang artinya $\mathrm{H}_{1}$ di terima dan $\mathrm{H}_{0}$ ditolak, dengan kata lain terdapat pengaruh yang signifikan antara luas lahan dan pendapatan.

2).Tenaga kerja diperoleh $t_{\text {hitung }}$ sebesar -2,222 dan $t_{\text {tabel }}$ sebesar 2.023, maka diperoleh hasil $t_{\text {hitung }}<t_{\text {tabel }}$ atau $-2,222<2,023$ dengan tingkat signifikan 0,004 $<0,05$ yang artinya $\mathrm{H}_{2}$ diterimah dan $\mathrm{H}_{0}$ di tolak,dengan kata lain terdapat pengaruh yang signifikan antara modal dan pendapatan.Modal diperoleh $t_{\text {hitung }}$ sebesar -3,086 dan $\mathrm{t}_{\text {tabel }}$ sebesar 2.023, maka diperoleh hasil $\mathrm{t}_{\text {hitung }}<\mathrm{t}_{\text {tabel }}$ atau -3,086 2,023 dengan tingkat signifikan $0,032<0,05$ yang artinya $\mathrm{H}_{3}$ diterimah dan $\mathrm{H}_{0}$ di tolak,dengan kata lain terdapat pengaruh yang signifikan antara tenaga kerja dan pendapatan.

b. Uji f

Uji f di gunakan untuk menguji koefisien regresi secara keseluruhan dan untuk mengetahui keberartian hubungan antara variabel inedependen secara bersama-sama dengan variabel dependen. Pengujian hipotesis akan menggunakan tingkat signifikan sebesar $5 \%=0,05$ hasil penelitian dengan menggunakan program SPSS V.21 dapat dilihat pada tabel berikut :

Tabel 4.13

Hasil regresi uji F

ANOVA $^{\text {b }}$

\begin{tabular}{|l|r|r|r|r|r|}
\hline Model & Sum of Squares & Df & Mean Square & F & \multicolumn{1}{|c|}{ Sig. } \\
\hline 1 Regression & 50.467 & 3 & 16.822 & 9.095 & $.000^{\mathrm{a}}$ \\
Residual & 72.138 & 39 & 1.850 & & \\
Total & 122.605 & 42 & & & \\
\hline
\end{tabular}

a. Predictors: (Constant), x3, x1, x2

b. Dependent Variable: y

sumber:data diolah tahun 2018

Hasil tabel 4.13 Memperlihatkan nilai $F_{\text {hitung }}$ sebesar 9,095 nilai ini yang akan menjadi statistik uji yang akan dibandingkan deengan nilai $\mathrm{F}_{\text {tabel }}$ yang dihitung dengan $\mathrm{df}_{1}$ (derajat bebas pembilang $)=3$ dan $\mathrm{df}_{2}($ derajat bebas penyebut $)=39$ maka diperoleh $\mathrm{F}_{\text {tabel }}$ sebesar 
2,46 berdasarkan nilai $F_{\text {hitung }}$ dan nilai $F_{\text {tabel }}$ yang telah didapat maka $F_{\text {hitung }}>F_{\text {tabel }}$ atau 9,095 > 2,46 dengan tingkat signifikan sebesar $0,000<0,05$ yang artinya $H_{a}$ diterima dan $H_{0}$ ditolak. Dengan kata lain bahwa secara simultan ( besama-sama ) pengaruh luas lahan, modal dan tenaga kerja berpengaruh terhadap pendapaataan.

\subsection{Pembahasan}

Hasil uji pengaruh Luas Lahan, Modal, dan Tenaga Kerja terhadap Pendapatan Petani Tambak Udang di Desa Tamuku Kecamatan Bone-Bone Kabupaten Luwu Utaraa.

\section{Pengaruh Luas Lahan terhadap Pendapatan petani tambak udang di Desa}

\section{Tamuku Kecamatan Bone-Bone Kabupaten Luwu Utara}

Berdasarkan hasil analisis stastistik di peroleh pengaruh Luas Lahan terhadap pendapatan dengan nilai koefisien sebesar $-0,298$ dan nilai signifikan 0,011<0,05. Hal ini menunjukkan bahwa variabel Luas lahan berpengaruh terhadap pendapatan.

Dengan demikian dapat di katakana bahwa semakin luas lahan yang di kelolah dalam bertani tambak udang maka semakin banyak pula pendapatan yang di peroleh petani tambak udang di Desa Tamuku. Sebaliknya jika makin sempit lahan yang di kelolah dalam usaha tani tambak udang maka semakin sedikit pula pendapatan yang di peroleh petani tambak udang di Desa Tamuku. Sehingga dapat disimpulkan bahwa Hipotesis 1 yang menyatakan bahwa Luas lahan berpengaruh signifikan dan positif terhadap pendapatan dapat diterima.

\section{Pengaruh Modal terhadap Pendapatan petani tambak udang di Desa Tamuku} Kecamatan Bone-Bone Kabupaten Luwu Utara.

Berdasarkan hasil analisis statistic di peroleh pengaruh Modal terhadap Pendapatan dengan niali koefisien sebesar $-0,371$ dan nilai signifikan sebesar $0,004<$ 0,05. Hal ini menunjukan bahwa variabel Modal berpengaruh terhadap Pendapatan.

Dengan demikian dikatankan bahwa semakin banyak modal yang digunakan untuk usaha tani tambak udang maka semakin banyak pula pendapatan yang akan di peroleh petani tambak udang di Desa Tamuku. Sebaliknya, jika semakin sedikit modal yang digunakan dalam usaha tani tambak udang maka semakin sedikit pula pendapatan yang diperoleh petaani tambak udang di Desa Tamuku. Sehingga dapat di simpulkan bahwa Hipotesis 2 yang menyatakan bahwa modal berpengaruh signifikan dan positif terhadap pendapatan dapat diterima. 


\section{Pengaruh tenaga kerja terhadap pendapatan petani tambak udang di Desa}

\section{Tamuku Kecamatan Bone-Bone Kabupaten Luwu Utara.}

Berdasarkan hasil analisis statistic di peroleh pengaruh Tenaga Kerja terhadap Pendapatan dengan niali koefisien sebesar -0,412 dan nilai signifikan sebesar 0,032< 0,05. Hal ini menunjukan bahwa variabel Tenaga Kerja berpengaruh terhadap Pendapatan.

Dengan demikian dikatankan bahwa semakin banyak Tenaga Kerja yang dipekerjakan dalan usaha tani tambak udang maka semakin banyak pula pendapatan yang akan di peroleh petani tambak udang di Desa Tamuku. Sebaliknya, jika semakin sedikit Tenaga Kerja yang dipekerjakan dalam usaha tani tambak udang maka semakin sedikit pula pendapatan yang diperoleh petaani tambak udang di Desa Tamuku. Sehingga dapat di simpulkan bahwa Hipotesis 3 yang menyatakan bahwa Tenaga Kerja berpengaruh signifikan dan positif terhadap pendapatan dapat diterima.

4. Variabel yang paling dominan berpengaruh terhadap pendapatan petani tambak udang di Desa Tamuku Kecamatan Bone-Bone Kabupaten Luwu Utara

Berdasarkan hasil analisis statistic uji parsial pengaruh luas lahan, modal dan tenaga kerja dengan masing-masing nilai signifikan adalah variabel luas lahan sebesar 0,011, dan variabel modal sebesar 0,004 dan variabel tenaga kerja sebesar 0,032. Dan variabel yang memiliki tingkat nilai signifikan sangat besar adalah variabel Modal dengan nilai signifikan sebesar 0,004

Dengan demikian dapat dikatakan bahwa variabel Modal adalah variabl yang paling dominan berpengaruh terhadap pendapatan petani tambak udang di Desa Tamuku kecamatan Bone-Bone Kabupaten Luwu Utara

\section{Simpulan dan Saran}

Berdasarkan hasil penelitian maka dapat di tarik kesimpulan sebagai berikut :

1. Luas lahan berpengaruh signifikan terhadap pendapatan petani tambak udang. Hal ini menunjukkan bahwa semakin luas lahan yang di gunakan untuk bertani tambak udang, maka semakin banyak pula kendapatan yang di peroleh dalam bertani tambak udang. Sebaliknya, jika makin sempit lahan yang di gunakan dalam bertani tambak udang maka sedikit pula pendapatan dan ditunjukkan dengan hasil uji SPSS 0.011 yang lebih kecil dari tingkat signifikan yaitu 0,05 . 
2. Modal berpengaruh signifikan terhadap pendapatan petani tambak udang. Hal ini menunjukkan bahwa semakin banyak modal yang digunakan untuk bertani tambak udang, maka semakin banyak pula pendapatan yang diperoleh dalam bertani tambak udang. Sebaliknya, jika semakin sedikit modal yang digunakan dalam bertani tambak udang maka sedikit pula pendapatan dan ditunjukkan dengan hasil uji SPSS 0,004 yang lebih kecil dari tingkat signifikan yaitu 0,05 .

3. Tenaga kerja berpengaruh signifikan terhadap petani tambak udang. Hal ini menunjukkan bahwa semakin banyak tenaga kerja yang di gunakan untuk bertani tambak udang, maka semakin banyak pula pendapatan yang di peroleh dalam bertani tambak udang. Sebaliknya, jika semakin sedikit tenaga kerja yang digunakan dalam bertani tambak udang maka sedikit pula pendapatan dan ditunjukkan dengan hasil uji SPSS 0,032 yang lebih kecil dari tingkat signifikan yaitu 0,032 .

Berdasarkan hasil penelitian ini, maka penulis mengajukan beberapa saran sebagai berikut :

1. Bagi parah petani tambak udang diharapkan agar lebih mampu membuat ide-ide baru untuk mengembangkan usahanya dalam bertani.

2. Bagi petani tambak udang di Desa Tamuku Kecamatan Bone-Bone agar terus meningkatkan kemampuan secara propesional dalam menekuni pekerjaannya serta menciptakan sistem kerja yang lebih efisien dan efektif.

3. Peneliti dalam hal ini sadar akan ketidak sempurnaan dalam penelitiannya, maka dari itu peneliti menyarangkan kepada peneliti berikutnya agar menambahkan variablevariabel lain yang mempengaruhi variable dependen dalam menyembangkan usaha tani agar dapat meningkatkan pendapatan petani. 


\section{Daftar Pustaka}

Direktorat Jenderal Perikanan Tangkap 2005 Perkembangan Produksi Perikanan, Kompas, Kamis 12 April 2007.

Http://www.lampungpost.com/cetak/berita.php?id=2006112900584741 [27 April 2009] 2 http://www.kompas.com/kompas-cetak/0506/27/ekonomi/1840817.htm - 40k [25 April 2009]

Josan , Fathorrozi, 2003. Teori ekonomi mikro. Salemba empat, Jakarta

Mubyarto, Pengantar ekonomi pertanian, Jakarta : LP3S, 2000

Rusmiyati, Sri. 2011. Sukses Budidaya udang dan Sunaryo, T. 2001.

Soekartawi. 2001. Prinsip Dasar Ekonomi Pertanian. Teori dan Aplikasi. Rajawali Press. Jakarta.

Sukirno, Sadono 2004. Pengantar Teori Mikro Ekonomi Raja Grafindo persada, Jakarta

Sukirno, sandono, 2001 Pengantar Teori Makro Ekonomi, Jakarta Universitas Malaya : Bima Grafika

Winardi, 2002. Pengantar Ilmu Ekonomi. Tarsito, Bandung

Zepriana, doni 2010 analisi faktor-faktor produksi dan pendapatan usaha budidaya udang di kabupaten ciamis 